\title{
The Ex-ante/Ex-post Perspectives of the Determinants of Capital Structure: An Integrated Analysis Approach
}

\author{
Tibuhinda Ngonzi, Andrew Jisaba \\ Department of Accountancy and Finance, St. Augustine University of Tanzania, Mwanza, Tanzania \\ Email address: \\ rigonzizk@gmail.com (T. Ngonzi),jisaba@yahoo.com (A. Jisaba) \\ To cite this article: \\ Tibuhinda Ngonzi, Andrew Jisaba. The Ex-Ante/Ex-Post Perspectives of the Determinants of Capital Structure: An Integrated Analysis \\ Approach. Journal of Finance and Accounting. Vol. 5, No. 1, 2017, pp. 12-23. doi: 10.11648/j.jfa.20170501.12
}

Received: December 20, 2016; Accepted: December 28, 2016; Published: January 21, 2017

\begin{abstract}
The implementation of capital structure decisions may take place at a point in time, while their effects are realized over time. The predisposition of the capital structure modifying factors as its 'determining variables' has an implication of posing the variables as drivers of capital structure decisions. However, the evidence research in corporate finance centres on determining variables ex-post at the influence of positive accounting theory and the presumptions of the tradeoff and pecking order theories. The impact of this perspective is realized in theoretical and operational controversies. This study uses ordinal regression to handle an integrated analysis of lagged variables on debt and investment opportunity financing and managerial subjective data to investigate their impact on capital structure. The outcome is such that there is no emergent pattern to suggest that there is any pecking order or capital structure monitoring, which drives decisions on capital structure a prior. The study suggests an understanding of the 'determinants of capital structure' as factors that operate in-situ to modify the proportions of capital and debt in assets through market driven financial transactions.
\end{abstract}

Keywords: Ex-post, Ex-ante, Capital Structure, Integrated Analysis, In-Situ

\section{Introduction}

Corporates are social entities, which do not behave in a uniform way even under the same circumstances, or when faced with similar situations. They are driven by privileged individuals as managers, who have capacity to make overriding choices. The behaviours of managers individually are part of some larger context in which the managers seek harmony of their organizations. In such circumstances, a hermeneutic process is useful to unravel the antecedent conditions of the environment, that the managers' hinge on as they proceed to individual actions. Thus, the managers' experiences and subjective meanings are assumed to be relevant in major corporate drivers such as capital structure. This is an unavoidable background to any organizational research, that writers and researcher have to avail a space even in accounting research programmes affiliated to positive paradigms such as Kabir [17], Watts and Zimmerman [31], Williams and Francis [34] etc.

Whether there is a universally optimal capital structure and how firms arrive at it is a long term persistent question in corporate finance that has attracted a lot of research. This is a question aroused by the fact that the prevailing corporate finance models, the trade-off and the pecking order theories in particular, are still inconclusive in attempts to explain the deviations of some empirical evidences from theoretical expectations. The Ju, Parrino, Poteshman and Weisback [16] for instance, have cited a voluminous literature which suggest that indeed companies do not strive to attain what would be the theoretically optimum capital structure. This correlates with the studies such as the one by Ngonzi [23].

The phenomenon genuinely prompts reasoning into the other possible circumstances beyond the literature hypothesized bankruptcy costs and differences in information [22], agency costs [16] and known firm specific characteristics such as firm size, asset tangibility, profitability, firm risk and growth opportunities [4, 8, 12]. The phenomenon has also defied the extensions on the determinants of capital structure which include the differences in market and non-market debt (private arrangements) [12], the relative amount of ownership claims held by insiders (management) versus outsiders (investors with no direct role in the management of the firm) [15]. Others are environmental and country specific factors that 
include the stages of development of bond and stock markets, legal enforcement, shareholder/creditor right protection, market or bank-based financial systems [7-8]. Frank and Goyal [10] provide and even richer list comprising of about 38 factors which cannot be exhaustively recited here.

We understand in this study that, there is an array of factors across firms with a significant diversity in characteristic, to the extent that it is not easily possible to have them demonstrate existence of unique capital structure or equilibrium like it is often reported in corporate finance 'evidence' studies. The problem is that most of such studies have remained richly descriptive while lacking on the explanatory dimension.

It is predicted in this study that the inclination to positivist approaches which are dominant in corporate finance research as evidenced in Huang and Song [13], tends to stress out the subjective values that are important in capturing behavioral patterns of managers as they control their capital structure. Within those approaches are the improper specifications of descriptive versus predictive models such as the inappropriate use of regressions and aggregated values [23], and non-closure or lack of appropriate conclusions. Note that there are four dimensions to modelling: (1) developing the form of the model which is dependent on the assumptions and theories; (2) specifying the model where the knowledge of econometrics becomes handy; (3) estimating the model, where observations are used to estimate the parameters such as the relationship coefficients and so on; and (4) the interpretations. In practice, errors can develop at any stage of the modelling process.

In essence, this study emphasizes the importance of including observations on subjective values as antecedent conditions prior to decisions on how much leverage to use in business, especially in financing for future investment opportunities. It is the antecedent context that this study refers to as the ex-ante in perspective. For practical purposes, this study has limited its scope to testing the yield of ex-post based evidence research on the determinants of capital structure vis-à-vis antecedent context prescriptions. This defines the problem of the study inter-alia.

The rest of the paper proceeds as follows. Section two presents a brief literature review, followed by an indicative survey of the methodologies in the empirical investigative works on the determinants of capital structure in Section 3. Section 4 presents this paper's adopted methodological approach. Findings and the discussion of findings appear in Section 5, while Section 6 presents the conclusions.

\section{Literature Review}

We start with a question: will the ex-ante context unravel different determinants of capital structure, hence different insights into the implications of the pecking order and tradeoff theories, from ex-post processes? For the conclusions existing in literature might be descriptive of the outcome of market activity forcing adjustments towards an optimal or equilibrium capital structure, we argue.

Some firms, especially emerging firms, tend to rely more on equity than debt [30]. This is predictable. The reason is that equity tends to spread risk, such as performance risk over many parties, while avoiding bankruptcy costs. It is therefore logical for young firms. But why is adjustment to benefit from tax shield of debt not observed through the mechanisms of financing future investment opportunities with debt when they start becoming profitable as the trade-off theory might suggest? This remains to be a question for investigation.

Huang and Song [13] suggest for the statistical test among the tradeoff and the pecking order hypotheses in order to draw a conclusion on "which is more powerful in explaining the firms' financing behavior" (p. 16). The suggested test contextualizes the two hypotheses as competitive against one another, the perception also expressed by Chen [6]. But, are they really competing against each other? Tong and Green [30], referring to Fama and French [9], have observed that many of the test variables "held to determine leverage under pecking order or trade-off theories are common to both theories" (p. 2181), thus not mutually exclusive of one another. This is also observed by Welch [32] that "there is no dichotomy between pecking order and tradeoff theory (p. 1).

We agree with Fama and Frech [9] that the spirit of two theories is to inform on the financing behavior of companies. In that context, the statistical relevance is relegated to only explaining the intensity of each line of financing choice, in turn diminishing the 'theory $\mathrm{A}$ is more powerful than theory B' conceptualization of capital structure 'determinants' in the corporate world.

Following the equilibrium theory, it must be true that the differences in the gains or forgone advantage by relying on the tradeoff or pecking order stipulated sequences respectively is of a temporary nature, applying in the shortrun. In the long-run the market mechanisms will iron out the differences. To clarify on this, let us see what happens when a firm has two options A and B to choose from for financing its investment opportunities.

Option A: go the tradeoff way. That is, use debt to finance investment up to the optimal capital structure. The cost benefit analysis involves bankruptcy (liquidation and financial distress) and agency (agency costs of equity and debt) costs versus tax benefit. The bankruptcy costs are reflected in liquidation and financial distress, while agency costs pertain to the use of equity and debt [22].

Option B: go the pecking order way. That is, according to the pecking order theory: in the presence of asymmetric information, a firm will prefer internal finance over debt, then debt over equity if internal finance is exhausted. Issuing new equity is the last alternative [21].

Now, if a firm chooses to use retained earnings to finance investment opportunities, it may lose on the tax shield advantage in the short term. However, in the long-run its stock is not discounted for risk by the market. In addition, the firm's stock enjoys a value (stock price) increase as an outcome of added profits from the added investment.

Alternatively, if the firm chooses to deploy debt to finance its investment opportunities, the effect is the market to discount the firm's revenues for debt risk. The firm gains on 
tax advantage. In the end, the market forces will bring in equilibrium, leaving the firm with equal benefits regardless of the financing route taken.

However, very limited attention has been paid in empirical research to establish the stance of researchers. The effect is that it is not known whether the observed determinants of capital structure play a role as the motives for Managers' choice of financing options as antecedent conditions, or they are the outcome of market adjustments. This limits the scope of knowledge in understanding the classification of the determinants and their evolution with time. It is also limiting on the understanding of the possible transitions that should take place as some variables such as size increase allowing for shifting from tradeoff to pecking order.

There is a difference when the empirically defined 'determinants of capital structure [5, 7-9, 13, 20, 25] are thought in the ex-post context and when alternatively contextualized. The ex-post tends to promote the cause-effect type of relationship between the 'determinants' as exogenous variables and 'capital structure' as an endogenous variable. The relationship is based on the magnitude of measurements $[1,6,24,30]$ with a gap on the logic. Most of the stipulated determinants feature in the statistical rigor, while they don't seem to be practically prerequisites in the managerial decision making process in the real time of sourcing of funds for investment financing. We therefore suggest in this study that, the empirically imputed numerical values when OLS methodology is applied would be more meaningful as correlational than cause-effect information. However, measurement or positive research stands the chances to be enriched if qualitative factors get included as well.

For instance, this paper's adopted ex-ante suggests that the observable relationship between some of the determinants and capital structure is a qualitative process. It cannot be verified and generalized on the basis of statistical explanations. Qualitative research is therefore, though less applied in finance research as the survey reveals later on, poised to be handy in revealing the firm distinguishing characteristics such as weak firms in emerging markets vis-àvis advanced markets. Unlike now where majority of research work wind up with gross conclusions such as [the observed] "positive relationships support the theoretical prediction of the trade-off theory" [14]; or [the] "negative relationship lends support to pecking order theory" [8].

Apart from the identified capital structure determinant factors in literature, there is a reality of the market growth stage. There are some characteristics that are unique to the emerging markets (which are again at different stages of growth) that differentiate them from advanced markets. For instance, Bekaert et al. [3] observe that "emerging markets cannot be characterised by expected returns, variance and covariance" (p.102); while Saudagaran and Diga [18] point out another unique characteristic as the flow of international capital into such markets that has not attained equilibrium yet, which is a limit to having market forces at a full operational level. Yet another evidence is from Ntui [24] who informs of the heavy reliance characteristic of firms at Dar es Salaam Stock Exchange (DSE) on bank borrowing, also supported by Hackbarth et al. [12] for "weak firms" (p. 1389) and the Welch's evidence of the effects of death and birth of firms on capital structure [33]. DSE is a very young market, probably ten years now. The impact of this kind of reliance is to discount the intensity of market debt and its reflections in the capital structure of respective companies.

Given the facts on the different characteristics of markets, we wonder as to why the conclusions of evidence studies should not be able to project differences in capital structure decisions? Majority of the studies show similarities or agreements to tradeoff and pecking order theory predictions without hinting on any differences between for instance, advanced markets and emerging markets (see the Findings column in Table 1).

It is in our observation in this paper that the studies on the evidence of the presence of perking order theory and tradeoff practices in the real world phenomena have enhanced the understanding of various factors related to the organizational states of capital structure as other literature observes [26], but not positions of managerial decisions on the debt-equity composition. This is further reflected in Ju, Parrino, Poteshman and Weisback [16] who trade it as the "central issue in corporate finance research" asking "why firms have fairly low leverage ratios despite the large tax advantage enjoyed by debt?" (p. 259), a question not answered by evidence research yet.

\section{Advances in Evidence for Capital Structure Decisions Research}

The body of research on exploring for the determinants of capital structure is predominantly driven by positivist perspectives as seen in the survey Table 1 .

Table 1. A Survey of Capital Structure Research.

\begin{tabular}{|c|c|c|c|}
\hline Publ & Title & Agenda and Methodology & Findings \\
\hline $\begin{array}{l}\text { Ahmad } \\
\text { Mohammad Obeid } \\
\text { Gharaibeh (2015) }\end{array}$ & $\begin{array}{l}\text { The Determinants of } \\
\text { Capital Structure: } \\
\text { Empirical Evidence. } \\
\text { From Kuwait }\end{array}$ & $\begin{array}{l}\text { To examine the determinants of capital } \\
\text { structure of industrial and services } \\
\text { firms listed in the Kuwait stock } \\
\text { exchange } 2009 \text { to } 2013 \text {. Multiple } \\
\text { regressions represented by ordinary } \\
\text { least squares (OLS) }\end{array}$ & $\begin{array}{l}\text { Firm's age, growth opportunities, liquidity, profitability, firm's } \\
\text { size, tangibility, and type of industry are key determinants of } \\
\text { capital structure of firms listed in Kuwaiti stock exchange } \\
\text { (KSE). } \\
\text { - Dividends policy and ownership structure do not show } \\
\text { relevance in the determination of capital structure }\end{array}$ \\
\hline $\begin{array}{l}\text { Thian Cheng Lim } \\
\text { (2012) }\end{array}$ & $\begin{array}{l}\text { Determinants of Capital } \\
\text { Structure Empirical } \\
\text { Evidence from Financial } \\
\text { Services Listed Firms in } \\
\text { China }\end{array}$ & $\begin{array}{l}\text { Investigates the determinants of capital } \\
\text { structure of financial service firms in } \\
\text { China; Using relative regression of } \\
\text { accounting data for } 36 \text { A-share financial } \\
\text { listed companies over the years } 2005 \text { - }\end{array}$ & $\begin{array}{l}\text { profitability, firm size, non-debt tax shields, earnings volatility } \\
\text { and non-circulating shares are significant influence factors in } \\
\text { financial sector. } \\
\text { - firm size is positively related to the corporate leverage ratio. } \\
\text { - Chinese institutional characteristics affect the capital choice }\end{array}$ \\
\hline
\end{tabular}




\begin{tabular}{|c|c|c|}
\hline Publication & Title & Agenda and Methodology \\
\hline & & 2009 \\
\hline $\begin{array}{l}\text { Antwi, Fiifi, Atta, } \\
\text { \& Zhao. (2012) }\end{array}$ & $\begin{array}{l}\text { Capital Structure and } \\
\text { Firm Value: Empirical } \\
\text { Evidence from Ghana }\end{array}$ & $\begin{array}{l}\text { Investigates the impact of Capital } \\
\text { Structure on Firm's value. Ordinary } \\
\text { least squares method of regression was } \\
\text { applied in the analysis involving } 34 \\
\text { Ghana Stock Exchange quoted comps. }\end{array}$ \\
\hline Irfan Ali (2011) & $\begin{array}{l}\text { Determinants of Capital } \\
\text { Structure: Empirical } \\
\text { Evidence from Pakistan }\end{array}$ & $\begin{array}{l}\text { This study investigates capital structur } \\
\text { of non-financial firms registered on } \\
\text { Karachi Stock Exchange (Pakistan) } \\
\text { from } 2003 \text { to } 2008 \text { to find which } \\
\text { independent variables determine the } \\
\text { capital structure of Pakistani firms. } \\
\text { Applies the OLS regression analysis }\end{array}$ \\
\hline
\end{tabular}

Frank, \& Goyal (2009)

Qian, Tian, \& Wiranto (2009)

Abe de Jong, R. Kabir, TT Nguyen (2008)

Serrasqueiro, \& Nunes (2008)

Huang, \& Song (2006)

Deesomsak

Paudyal, \&

Pescetto (2004)

Raghulam G. Rajan and Luigi Zingales (1995)
Do Chinese publicly listed companies adjust their capital structure toward a target level?

Capital Structure around Analyses the importance of firmthe World: The roles of Firms and Country specific determinants

Determinants of Capita Structure: Comparison of. Empirical Evidence from the Use of Different Estimators

The determinants of capital structure: Evidence from China

The determinants of capital structure: evidence from the Asia Pacific region

What Do We Know about Capital Structure? Some Evidence from International Data
Examines the relative importance of many factors in the capital structure decisions of publicly traded American Firms from 1950 to 2003.

Study the determinants of capital structure for 650 Chinese publicly listed companies over the period from 1999 to 2004.

specific and country specific factors in the leverage choice of firms around the globe

Investigates the determinants of debt, where the results of static and dynamic panel models are compared for any differences

1. Investigates for the differences in capital structure decisions among private firms in market economies versus state owned firms in the Chinese economy, 2. Interrogates the factors that affect cross-sectional variability of capital structure for similarity of effects on Chinese firms as it is for developed and developing countries.

Investigates the determinants of capital structure of firms operating in the Asia Pacific region (Thailand, Malaysia, Singapore and Australia)

Investigates the determinants of capital structure choice by analysing the financing decisions of public firms in the major industrialized countries.
Findings

decision.

- State ownerships do affect capital structure choices.

- -Equity Capital is relevant to the value of the firm

- -long-term debt is a major determinant of a firm's value

- statistically significant coefficients for profitability, size, tangibility, growth, dividend and inflation.

- negative relationships between profitability and leverage; positive relationships between growth and long term debt and dividend and total debt of firms confirming the presence of pecking order theory in determining the financing behaviour of Pakistani firms.

- Strong positive relationships between tangibility and leverage and size and leverage support the theoretical predictions of trade-off theory.

- The positive relationship between expected future inflation and current borrowing supports market timing theory.

- The most reliable factors for explaining market leverage are: median industry leverage ( + effect on leverage), market-tobook assets ratio (-), tangibility $(+)$, profits $(-), \log$ of assets $(+)$, and expected inflation $(+)$

- dividend-paying firms tend to have lower leverage. - for book leverage, the impact of firm size, the market-to-book ratio, and the effect of inflation are not reliable.

- empirical evidence seems reasonably consistent with some versions of the trade-off theory of capital structure.

- Chinese firms adjust toward an equilibrium level of debt ratio in a given year at a very slow rate;

- firm size, tangibility and state shareholdings are positively associated with firm's leverage ratio, while profitability, nondebt tax shields, growth and volatility are negatively related to firm's leverage ratio;

- lagged profitability has a negligibly small and positive impact on firm's leverage ratio;

- Chinese firms tend to adjust faster if they are farther away from the equilibrium leverage level.

- The firm specific determinants of leverage differ across countries

- There is an indirect impact of country specific factors on the capital structure, where the CSF tend to influence the roles of firm specific determinants of leverage

- No significant deference in the results among the two models

- Portuguese companies resort less to debt

- Portuguese companies prefer internal capital to external sources

- Large companies resort more to debt

- Leverage in Chinese firms increases with firm size, profitability, non-debt tax shield, growth opportunities, managerial shareholdings and industry.

- Chinese companies consider tax effects on long-term debt financing

- Chinese companies tend to have lower long-term debt

-state ownership don't affect capital structure

- Determinants of capital structure varies across countries in the region

- firm size has a positive effect on capital structure -a negative effect of growth opportunities, non-debt tax shield, liquidity and share price performance on leverage was observed, a characteristic in support of the p-order theory

- At an aggregate level, firm leverage is fairly similar across the G-7 countries.

- Despite the similarity, the theoretical underpinnings are still largely unresolved 


\section{Methodology}

This study sought to investigate for the links between the theoretical predictions of optimal capital structure, pecking order, and tradeoff hypotheses and the managerial subjective factors in the financing of investment opportunities in companies.

The study assumed a presence of a desire to use reserves or debt to be a latent variable, dependent on the knowledge of the prevailing proportion of debt in net assets as a lagged variable, and an implicitly aligned pecking order in the cognitive of managers.

On the basis of the stated assumption, observations are sought on the visible outcome, which are the opportunity financing options actually implemented as obtains in the companies' financial data and lagged debt ratio. The operationalized model is specified as follows.

\subsection{Model Specification}

An index $\boldsymbol{\Psi}$ is assumed to be a scale used to represent the degree of the strength of the desire of a firm's decisions to avoid using debt in favour of reserves (or retained earnings) dependent on the debt level measured as $\boldsymbol{D} / \boldsymbol{A}$. The index is further assumed to be a random, continuous and normally distributed, however unobservable and unmeasurable factor. The two characteristics are respectively expressed as in (1) and (2):

$$
\begin{aligned}
& \Psi=\alpha_{0}+\alpha_{1}(D / A) \\
& \text { Where } \Psi \sim \mathrm{N}\left(\left(\boldsymbol{\mu}_{\varphi}, \sigma_{\varphi}^{2}\right)\right.
\end{aligned}
$$

to mean that $\Psi$ is normally distributed with mean $\boldsymbol{\mu}$ and standard deviation $\boldsymbol{\sigma}$.

At this point, the challenge is to determine the relationship between the unobservable and unmeasurable index $\boldsymbol{\Psi}$, and the observations on $\boldsymbol{D} / \boldsymbol{A}$. For the purpose, we consider the two extreme states of $\boldsymbol{\Psi}$ to be represented by dummy binary values $\boldsymbol{0}$ and 1 . The index $\boldsymbol{\Psi}$ assumes a value of $\boldsymbol{0}$ when it is observed that a firm has used reserves to finance investment opportunities at an observed value of $\boldsymbol{D} / \boldsymbol{A}$, and $\boldsymbol{1}$ when it used debt. In the other words, $\boldsymbol{\Psi}$ is dichotomous. Including the assumptions in model (1), the model is re-stated as follows:

$$
\Psi=\alpha_{0}+\alpha_{1}(D / A)_{i}+\varepsilon_{i}
$$

Where

$$
\begin{gathered}
\Psi_{i}=\left\{\alpha_{0}+\alpha_{1}(D / A)\right) \text { when } 0<\alpha_{0}+\alpha_{1} \boldsymbol{D} / \boldsymbol{A}_{i}<1 \\
=\left\{1 \text { when } \alpha_{0}+\alpha_{1} \boldsymbol{D} / \boldsymbol{A}_{i} \geq 1\right. \\
=\left\{0 \text { when } \alpha_{0}+\alpha_{1} D /_{A_{i}} \leq 0 .\right.
\end{gathered}
$$

For empirical inputs, $\Psi_{i}$ is attributed as follows:

$$
\Psi_{i}=\left\{\begin{array}{c}
0 \text { if a firm is found to have not borrowed to finance additional investment } \\
1 \text { if a firm is found to have borrowed to finance additional investment }
\end{array}\right.
$$

$\varepsilon_{i}$ is an independently distributed random variable

If the ratio $D / A$ is used as a driver, the likelihood that a firm will favour the use of reserves over borrowing increases with the increase in the ratio (Figure 1). That is if the tradeoff theory consistently holds.

The plotting in Figure 1 actually depicts a cumulative probability distribution function. Having established the link between observable and non-observable variables of the model in (1), the estimation of the parameters $\boldsymbol{\alpha}_{\mathbf{0}}$ and $\boldsymbol{\alpha}_{\mathbf{1}}$ is the next task facilitated by logit modelling.

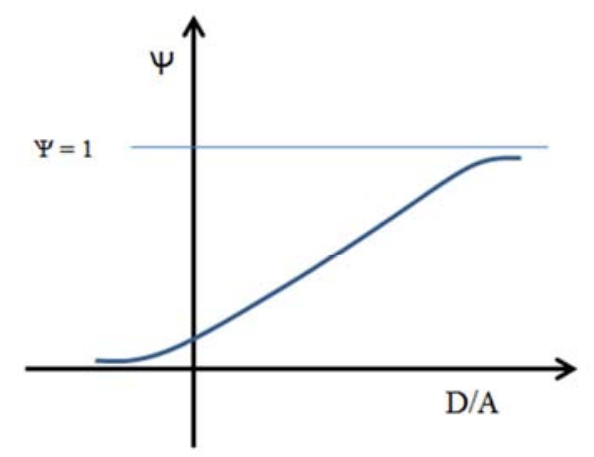

A

Figure 1. The increasing likelihood to use reserves over borrowing with increasing Debt ratio.

\subsection{The Logit Model}

The logit regression is a nonlinear regression model specifically designed for binary dependent variables. It is based on the logistic probability distribution function which produces probabilities between 0 and 1 . The logistic function is given by the expression following on from equation (3) as:

$$
P_{i}=F\left(\alpha_{0}+\alpha_{1} D / A_{i}\right)
$$

Where the respective logit model is expressed as

$$
P_{i}=\frac{1}{1+e^{-\left(\alpha_{0}+\alpha_{1} D / A_{i}\right)}}
$$

The $\mathrm{P}_{\mathrm{i}}$ in the model represents the probability that firm ' $\mathrm{i}$ ' will choose to use internal sources to finance a growth opportunity given the knowledge of $D / A_{i}$.

From (5),

$$
\begin{aligned}
& \text { If } P_{i}=\frac{1}{1+e^{-\left(\alpha_{0}+\alpha_{1} D / A_{i}\right)}} \text {, then } \\
& 1-P_{i}=\frac{1}{\left.1+e^{\left(\alpha_{0}+\alpha_{1} D / A i\right.}\right)}
\end{aligned}
$$

leading to the odd ratio: 


$$
\frac{P_{i}}{1-P_{i}}=e^{\left(\alpha_{0}+\alpha_{1} D / A_{i}\right)}
$$

that yields the logit Li by taking its natural logarithms as:

$$
\begin{gathered}
\mathrm{Li}=\ln \left(\frac{P_{i}}{1-P_{i}}\right)=\alpha_{0}+\alpha_{1} D / A_{i} \\
\mathrm{Li}=\ln \left(\frac{P_{i}}{1-P_{i}}\right)
\end{gathered}
$$

It can be observed from (8) that the logit $\mathrm{L}_{\mathrm{i}}$ is linear in $D / A_{i}$, which is a crucial characteristic providing a gateway for the use of OLS methods to estimate the parameters if $\mathrm{Li}$ can be observed.

For the parameters estimation in this study, observations were made on the lagged values of D and A (that is in period $\mathrm{t}-1$ ), while the logits $\mathrm{Li}$ were correspondingly derived

\begin{tabular}{|c|c|c|c|c|c|}
\hline $\begin{array}{l}\text { Characteristi } \\
\text { c ratio } \\
\left(D / A_{i}\right)\end{array}$ & $\begin{array}{l}\text { Number of } \\
\text { observations with that } \\
\text { characteristic }(\mathbf{N})\end{array}$ & $\begin{array}{l}\text { No. of observations within } N \\
\text { where Internal source of } \\
\text { funding was used } \Psi=1 \text { (ni) }\end{array}$ & $\begin{array}{l}\frac{n_{i}}{N_{i}}(\text { relative frequency })=P i \text { i.e the } \\
\text { probability of going for internal } \\
\text { funding at that observed debt ratio }\end{array}$ & $\begin{array}{l}\frac{P_{i}}{1-P_{i}} \text { Odd ratio } \\
\text { estimate }\end{array}$ & $\begin{array}{l}\text { Logit estimate } \\
(\mathrm{Li})=\ln \left(\frac{P_{i}}{1-P_{i}}\right)\end{array}$ \\
\hline$\ldots$ & $\ldots$ & $\ldots$ & $\ldots$ & $\ldots$ & $\ldots$ \\
\hline
\end{tabular}
observations as in (9) for period ( $\mathrm{t}$ ) (Table 2).

Table 2. Observations for the model estimation.

Adopted from Mukras (1993, p. 557)

However, the statistical package for social scientists (SPSS) has an 'ordinal logistic regression' facility which easily derives the parameter estimates. The same was applied in the analysis for the output discussed in the next section.

\subsection{Data for Analysis}

Data for analysis were collected with respect to four specific questions in focus: 1) Does a prior knowledge of the proportion of debt in assets (the status of capital structure) have a significant relationship with the adopted opportunity investment financing option (reserves or borrowing) in the firms? 2) Is there a prevalent pecking order among financial managers that is linkable with the investment financing options as adopted by the firms? 3) Do the observed use of reserves or debt relate to the managers subjective preferences of reserves over debt or vice versa? And 4) Does the prevailing debt ratio influence subjective financing option preferences (reserves over debt or vice versa)?

The Dar es Salaam stock exchange (DSE) was purposefully selected as a source of data on listed companies. Financial reports were used for data on investment opportunities financing processes and capital structure proxied by the proportion of debt in net assets. The subjective data were obtained from the respective management of the listed companies whose financial data were used. Questionnaires were used to capture managerial information on how the managers preferred to sequence their appropriation of financing resources assuming an affinity for investment; the considerations they have on capital structure when exploiting reserves or debt resources; and the subjective opportunity financing preferences given using debt or reserves.

Observations were made on the changes in net assets levels $(\Delta \mathrm{A})$ from period to period for each individual listed company. Wherever a change was noted, the corresponding change in equity $(\Delta \mathrm{E})$ and financial liabilities $(\Delta \mathrm{D})$ were observed and compared. Where the increase in equity exceeded the increase in debt, the increase in net assets was assumed to have been financed from reserves and vice versa. A ' 0 ' value observation was recorded wherever the net difference between the two parameters was in favour of $\Delta \mathrm{E}$ and ' 1 ' otherwise. The one period lagged $D_{t-1} / A_{t-1}$ ratio was computed, assuming that each period's financing decision was only affected by the already existing and the outcome statuses of this ratio. In the other words, apart from the existing ratio, any extra borrowing would also consider the outcome capital structure. In essence, if the optimal level is already reached, further borrowing would be restrained by assumption.

The two sets of data, subjective managerial data and lagged debt ratios, were analysed in integration using ordinal logistic regression. The approach was chosen to facilitate a holistic conceptualization of quantitative and essentially categorical subjective data. It is important to note however that, all the measurements to be used in the regression must be expressed in logically perceivable categories for this method to work perfectly. In addition, logical grouping might be essential for numeric data as it was the case with the established debt ratio classes in this study.

\section{Analysis and Discussion}

Ordinal regressions were run in SPSS, where the dependent ('threshold') and their respective independent ('location') factors were specified according to the stated specific questions in the previous section.

\subsection{Testing for the Relationship Between Existing Proportions of Debt in Assets and the Deployed Opportunity Financing Options}

Investment financing option in the first question is specified as a dichotomous dependent variable. Its two states were: ' 0 ' where the firm used reserves to finance additional assets observed as net change in equity $(\Delta \mathrm{E})$ in a firms' financial report data, and ' 1 ' where the firm used debt, observed as excess of change in debt $(\Delta \mathrm{D})$ over change in equity. The independent variable, lagged debt ratio, was a categorical variable with 17 classes which were used to group debt ratios as shown in the summary of cases that were processed in Table 3. The same table presents the parameter estimates output of the SPSS's ordinal regression. 
Table 3. Financing Option by Debt-ratio test.

\begin{tabular}{|c|c|c|c|c|c|c|c|c|}
\hline \multicolumn{9}{|c|}{ Case Processing Summary } \\
\hline & & & & \multicolumn{3}{|l|}{$\mathbf{N}$} & \multicolumn{2}{|c|}{ Marginal Percentage } \\
\hline \multirow{2}{*}{\multicolumn{2}{|c|}{ Observed financing source in data }} & \multicolumn{2}{|c|}{ Reserves-Financed (0) } & \multicolumn{3}{|l|}{61} & \multicolumn{2}{|l|}{$71.8 \%$} \\
\hline & & \multicolumn{2}{|c|}{ Debt-Financed (1) } & \multicolumn{3}{|l|}{24} & \multicolumn{2}{|l|}{$28.2 \%$} \\
\hline & & \multicolumn{2}{|l|}{$0-4$} & \multicolumn{3}{|l|}{18} & \multicolumn{2}{|l|}{$21.2 \%$} \\
\hline & & \multicolumn{2}{|l|}{$5-9$} & \multicolumn{3}{|l|}{21} & \multicolumn{2}{|l|}{$24.7 \%$} \\
\hline & & \multicolumn{2}{|l|}{$10-14$} & \multicolumn{3}{|l|}{16} & \multicolumn{2}{|l|}{$18.8 \%$} \\
\hline & & \multicolumn{2}{|l|}{$15-19$} & \multicolumn{3}{|l|}{8} & \multicolumn{2}{|l|}{$9.4 \%$} \\
\hline & & \multicolumn{2}{|l|}{$20-24$} & \multicolumn{3}{|l|}{5} & \multicolumn{2}{|l|}{$5.9 \%$} \\
\hline & & \multicolumn{2}{|l|}{$25-29$} & 2 & & & $2.4 \%$ & \\
\hline Debt ratio c & & $30-34$ & & 3 & & & $3.5 \%$ & \\
\hline & & $40-44$ & & 1 & & & $1.2 \%$ & \\
\hline & & $45-49$ & & 2 & & & $2.4 \%$ & \\
\hline & & $55-59$ & & 3 & & & $3.5 \%$ & \\
\hline & & $65-69$ & & 1 & & & $1.2 \%$ & \\
\hline & & $70-74$ & & 1 & & & $1.2 \%$ & \\
\hline & & $85-89$ & & 4 & & & $4.7 \%$ & \\
\hline Valid & & & & 85 & & & $100.0 \%$ & \\
\hline Missing & & & & 0 & & & & \\
\hline Total & & & & 85 & & & & \\
\hline Parameter I & ates & & & & & & & \\
\hline & & Fstimate & Std Frror & Wald & $\mathrm{df}$ & $\mathrm{Sig}$ & $95 \%$ Confiden & terval \\
\hline & & Lstimiate & Stu. Li101 & wraid & ai & SIg. & Lower Bound & Upper Bound \\
\hline Threshold & {$[$ OpFinancing = 0] } & -1.099 & 1.155 & .905 & 1 & .341 & -3.362 & 1.165 \\
\hline & {$[$ DratioClasses $=0]$} & -19.573 & 2421.641 & .000 & 1 & .994 & -4765.902 & 4726.755 \\
\hline & {$[$ DratioClasses $=1]$} & -2.890 & 1.312 & 4.851 & 1 & .028 & -5.463 & -.318 \\
\hline & {$[$ DratioClasses $=2]$} & -2.197 & 1.291 & 2.897 & 1 & .089 & -4.728 & .333 \\
\hline & [DratioClasses $=3]$ & -1.099 & 1.354 & .658 & 1 & .417 & -3.752 & 1.555 \\
\hline & {$[$ DratioClasses $=4]$} & -2.485 & 1.607 & 2.390 & 1 & .122 & -5.635 & .665 \\
\hline & {$[$ DratioClasses $=5]$} & 17.623 & 8220.220 & .000 & 1 & .998 & -16093.712 & 16128.958 \\
\hline Location & {$[$ DratioClasses $=6]$} & -.405 & 1.683 & .058 & 1 & .810 & -3.705 & 2.894 \\
\hline & {$[$ DratioClasses $=8]$} & -19.573 & .000 & . & 1 & . & -19.573 & -19.573 \\
\hline & [DratioClasses $=9]$ & 17.623 & 8220.220 & .000 & 1 & .998 & -16093.712 & 16128.958 \\
\hline & {$[$ DratioClasses $=11]$} & -.405 & 1.683 & .058 & 1 & .810 & -3.705 & 2.894 \\
\hline & [DratioClasses $=13$ ] & 17.623 & .000 & . & 1 & . & 17.623 & 17.623 \\
\hline & [DratioClasses=14] & -19.573 & .000 & . & 1 & . & -19.573 & -19.573 \\
\hline & [DratioClasses $=17]$ & $0^{\mathrm{a}}$ & . & . & 0 & & . & . \\
\hline
\end{tabular}

Link function: Logit.

a. This parameter is set to zero because it is redundant.

In Table 3, the debt ratio percentages are treated as conditional categories. The probability for the binary financing option variable events is estimated by the function in equation (5), where $P_{i}=\frac{1}{1+e^{-\left(\alpha_{0}+\alpha_{1} D / A_{i}\right)}}$.

The coefficient estimate (-1.099) for the threshold observation on the actual opportunity financing resource used coded [OpFinancing $=0$ ] is an intercept $\boldsymbol{\alpha}_{\mathbf{0}}$ in the function. The other estimates for the 'location' variable or debt ratios coded [DratioPercent] are the coefficients $\boldsymbol{\alpha}_{1 \text { to } n-1}$ for each class category of D/A. Just as a hint, the output of SPSS can also include the logits as expressed in equation $(8) \mathrm{Li}=$ $\left(\frac{P_{i}}{1-P_{i}}\right)=\alpha_{0}+\alpha_{1} D / A_{i}$. The option was not requested in the analysis output in the case of this paper for the observed high significance level values, which possibly lead to the acceptance of the null hypothesis stated as 'No relationship between the category of location factor and thresholds categories'. The alternative is 'the respective categories are related' if the relating parameters have a significance level of 0.05 or less.

The output in Table 3 shows that the parameter estimates for debt ratio classes ( $\boldsymbol{\alpha}_{\boldsymbol{i}}$ coefficients) are almost all significant (well above 0.05 ) except [DratioClasses $=1$ ] a code for the $5-9 \%$ debt ratio class category which is -2.890 ( 0.028 significance level). This outcome is an indication that there is no statistical evidence to suggest that the choice of reserves to finance investment opportunities in a firm is related to the existing debt ratio or capital structure. The negative parameters depict an inclination of managers to the use of reserves. 


\subsection{Testing for the Existence of Influential Pecking Order in the Choice of Opportunity Financing Options in Organizations}

The respondents were requested to write down the order of preference in considering the options available to them as they appropriate the resources to finance investment opportunities. Five orders were identifies as:

[1] Reserves - Borrowing - Issue Equity

[2] Reserves - Borrowing - Preferred Shares - Issue
Equity

[3] Reserves - Issue Equity - Borrowing

[4] Reserves - Borrowing

[5] Issue Equity - Reserves - Borrowing

The output of the ordinal regression for the test on the 'existence of a relationship between the actual opportunity financing resource used coded [OpFinancing] and the subjectively expressed pecking order' as per questionnaire responses appears in Table 4.

Table 4. Financing option by Pecking Order Test.

\begin{tabular}{|c|c|c|c|c|c|c|c|c|}
\hline \multicolumn{9}{|c|}{ Case Processing Summary } \\
\hline & & & & & & & $\mathbf{N}$ & Marginal Percentage \\
\hline \multirow{2}{*}{\multicolumn{2}{|c|}{ Observed financing source in data }} & \multicolumn{5}{|c|}{ Reserves-Financed } & 61 & $71.8 \%$ \\
\hline & & \multicolumn{5}{|c|}{ Debt-Financed } & 24 & $28.2 \%$ \\
\hline \multirow{4}{*}{\multicolumn{2}{|c|}{ Preference Financing ranking }} & \multicolumn{5}{|c|}{ Retained Earnings, Borrowing, PreferenceShares, IssueEquity } & 33 & $38.8 \%$ \\
\hline & & \multicolumn{5}{|c|}{ Retained Earnings, IssueEquity, Borrowing } & 43 & $50.6 \%$ \\
\hline & & \multicolumn{5}{|c|}{ Retained Earnings, Borrowing } & 6 & $7.1 \%$ \\
\hline & & \multicolumn{5}{|c|}{ IssueEquity, Retained Earnings, Borrowing } & 3 & $3.5 \%$ \\
\hline \multicolumn{7}{|l|}{ Valid } & 85 & $100.0 \%$ \\
\hline \multicolumn{7}{|l|}{ Missing } & 0 & \\
\hline \multicolumn{7}{|l|}{ Total } & 85 & \\
\hline \multicolumn{9}{|c|}{ Parameter Estimates } \\
\hline & & \multirow{2}{*}{ Estimate } & \multirow{2}{*}{ Std. Error } & \multirow{2}{*}{ Wald } & \multirow{2}{*}{ df } & \multirow{2}{*}{ Sig. } & $95 \%$ Confiden & aterval \\
\hline & & & & & & & Lower Bound & Upper Bound \\
\hline Threshold & {$[$ OpFinancing $=0]$} & -.693 & 1.225 & .320 & 1 & .571 & -3.094 & 1.707 \\
\hline \multirow{4}{*}{ Location } & {$[$ PekingOrder $=1]$} & -2.005 & 1.297 & 2.392 & 1 & .122 & -4.547 & .536 \\
\hline & [PekingOrder=2] & -1.421 & 1.267 & 1.258 & 1 & .262 & -3.905 & 1.062 \\
\hline & [PekingOrder=3] & -2.303 & 1.643 & 1.964 & 1 & .161 & -5.523 & .918 \\
\hline & [PekingOrder $=4]$ & \multicolumn{2}{|l|}{$0^{\mathrm{a}}$} & & 0 & & . & \\
\hline
\end{tabular}

Link function: Logit.

a. This parameter is set to zero because it is redundant.

Again the coefficient estimate for the threshold observation [OpFinancing $=0$ ], an intercept $\boldsymbol{\alpha}_{\mathbf{0}}$, is found to be -0.693 but with a significance level of 0.571 . The estimates for the 'location' [PeckingOrder] are the coefficients $\boldsymbol{\alpha}_{1 \text { to } 4}$ for each pecking order category 1 to 4 . Their corresponding significance levels appear in column six, all being above 0.05 . This implies that there is no revealed relationship between any pecking order and the choice of financing option.

In the broad sense, the financing option, which in turn reflects the decisions on capital structure, can be said to be not driven by the discretion of managers. Probably it is driven by a range of circumstances at the time, hence a confirmation that the observed pecking order or capital structure in organizations is an outcome of long-term adjustments and not decisions in the short-term.

\subsection{Testing Whether the Use of Reserves or Debt Is a Deliberation of Managers Driven by Their Subjective Preferences}

The analysis for the third question appears in Table 5. This is about whether the financial managers' preference of using either reserves or debt to finance investment opportunities has an influence on the ultimately observed financing resource used.

The dependent factor specified was the actual financing option coded [OpFinancing] with values 'Reserves financed $=0$ ' and 'Debt financed $=1$ '. The independent factor coded [DebToResPref] was whether the manager would prefer using debt [DebToResPref $=1]$ or not $[=0]$ as an option for financing investment opportunities.

The ordinal regression parameter estimates are 0.511 (0.323 significance) for $\boldsymbol{\alpha}_{\mathbf{0}}$ coefficient in [OpFinancing $=0$ ] category, and -0.531 (0.364 significance) for $\alpha_{1}$ coefficient in [DebToResPref $=0$ ] 'don't prefer using debt' category of the independent factor.

The estimated values for the parameters $\boldsymbol{\alpha}_{\mathbf{0}}$ and $\boldsymbol{\alpha}_{\mathbf{1}}$ are seen to have significance levels above the 0.05 cut off, thus showing no enough statistical evidence for the existence of influential relationship between the managers' preferences and the actually used opportunity financing resource. However, a negative coefficient on the estimator category [DebToResPref $=0]$ is an indication that the 'no debt' preference increases the odds for the choice of other resources over borrowing. 
Table 5. Financing option by Subjective Financing Preference Test.

\begin{tabular}{|c|c|c|c|c|c|c|c|c|}
\hline \multicolumn{9}{|c|}{ Case Processing Summary } \\
\hline & & & & & & $\mathbf{N}$ & \multicolumn{2}{|c|}{ Marginal Percentage } \\
\hline \multirow{2}{*}{\multicolumn{2}{|c|}{ Observed financing source in data }} & \multicolumn{3}{|c|}{ Reserves-Financed } & & 61 & \multicolumn{2}{|l|}{$71.8 \%$} \\
\hline & & \multicolumn{3}{|c|}{ Debt-Financed } & & 24 & \multicolumn{2}{|l|}{$28.2 \%$} \\
\hline \multirow{2}{*}{\multicolumn{2}{|c|}{$\begin{array}{l}\text { Would you prefer borrowing to finance an } \\
\text { opportunity? }\end{array}$}} & \multicolumn{3}{|c|}{ No-Dont prefer borrowing $(0)$} & & 69 & \multicolumn{2}{|l|}{$81.2 \%$} \\
\hline & & \multicolumn{3}{|c|}{ Yes-PreferBorrowing (1) } & & 16 & $18.8 \%$ & \\
\hline \multicolumn{5}{|l|}{ Valid } & & 85 & \multicolumn{2}{|l|}{$100.0 \%$} \\
\hline \multicolumn{5}{|l|}{ Missing } & & \multicolumn{3}{|l|}{0} \\
\hline \multicolumn{5}{|l|}{ Total } & & \multicolumn{3}{|l|}{85} \\
\hline \multicolumn{9}{|c|}{ Parameter Estimates } \\
\hline & & \multirow{2}{*}{ Estimate } & \multirow{2}{*}{ Std. Error } & \multirow{2}{*}{ Wald } & \multirow{2}{*}{$\mathrm{df}$} & \multirow{2}{*}{ Sig. } & \multicolumn{2}{|c|}{$95 \%$ Confidence Interval } \\
\hline & & & & & & & Lower Bound & Upper Bound \\
\hline Threshold & {$[$ OpFinancing $=0]$} & .511 & .516 & .979 & 1 & .323 & -.501 & 1.523 \\
\hline \multirow{2}{*}{ Location } & {$[$ DebToResPref $=0]$} & -.531 & .585 & .824 & 1 & .364 & -1.677 & .615 \\
\hline & {$[$ DebToResPref=1] } & $0^{\mathrm{a}}$ & & & 0 & & & . \\
\hline
\end{tabular}

Link function: Logit.

a. This parameter is set to zero because it is redundant.

\subsection{Testing for the Existence of Any Driving Force \\ Inherent in the Incumbent Proportion of Debt in Assets \\ Over Subjective Opportunity Financing Option \\ Preferences}

An ordinal regression to test for whether the status of capital structure as measured by debt ratio has an influence on the subsequent financing option preference between debt and reserves, the fourth question of the study, yields the coefficient estimates presented in Table 6 . In the other words, this test checks if capital structure is monitored, to the extent of maintaining a certain theoretically optimal level. In such a case, a manager would shift gears between debt and reserves to make sure an optimal level is not violated.

From the observed significance levels, the outcome ordinal regression estimates $\boldsymbol{\alpha}_{\mathbf{0}}$ for the dependent factor (financing preference) coded [DebToResPref $=0$ for 'do not prefer borrowing' and $=1$ for 'prefer borrowing'] and $\boldsymbol{\alpha}_{\mathbf{1} \text { to } n-1}$ for the independent factor Debt ratio classes (coded [DratioClasses]) categories in Table 6 manifest a lack of relationship between the factors. Not even do any classes of capital structure arouse a concern among the decision makers.

Table 6. Financing Preference in relation to Prevalent Debt Ratio.

\begin{tabular}{llll}
\hline Case Processing Summary & & & \\
\hline & & M & Marginal Percentage \\
\hline Would you prefer borrowing to finance an & No-Dont prefer borrowing & 69 & $81.2 \%$ \\
opportunity? & Yes-PreferBorrowing & 16 & $18.8 \%$ \\
& $0-4$ & 18 & $21.2 \%$ \\
& $5-9$ & 21 & $24.7 \%$ \\
& $10-14$ & 16 & $18.8 \%$ \\
& $15-19$ & 8 & $9.4 \%$ \\
& $20-24$ & 5 & $5.9 \%$ \\
Debt ratio classes & $25-29$ & 2 & $3.4 \%$ \\
& $30-34$ & 3 & $1.2 \%$ \\
& $40-44$ & 1 & $2.4 \%$ \\
& $45-49$ & 2 & $3.5 \%$ \\
& $55-59$ & 3 & $1.2 \%$ \\
Valid & $65-69$ & 1 & $1.2 \%$ \\
Missing & $70-74$ & 1 & $4.7 \%$ \\
Total & $85-89$ & 4 & $100.0 \%$ \\
\hline
\end{tabular}




\begin{tabular}{|c|c|c|c|c|c|c|c|c|}
\hline \multicolumn{9}{|c|}{ Parameter Estimates } \\
\hline & & \multirow{2}{*}{ Estimate } & \multirow{2}{*}{ Std. Error } & \multirow{2}{*}{ Wald } & \multirow{2}{*}{ df } & \multirow{2}{*}{ Sig. } & \multicolumn{2}{|c|}{ 95\% Confidence Interval } \\
\hline & & & & & & & Lower Bound & Upper Bound \\
\hline \multirow[t]{7}{*}{ Threshold } & {$[$ DebToResPref $=0]$} & 1.099 & 1.155 & .905 & 1 & .341 & -1.165 & 3.362 \\
\hline & {$[$ DratioClasses $=0]$} & -.154 & 1.286 & .014 & 1 & .905 & -2.675 & 2.367 \\
\hline & {$[$ DratioClasses $=1]$} & -.348 & 1.281 & .074 & 1 & .786 & -2.860 & 2.163 \\
\hline & {$[$ DratioClasses $=2]$} & -.368 & 1.320 & .078 & 1 & .781 & -2.956 & 2.220 \\
\hline & [DratioClasses $=3$ ] & $-2.182 \mathrm{E}-016$ & 1.414 & .000 & 1 & 1.000 & -2.772 & 2.772 \\
\hline & [DratioClasses $=4]$ & -17.699 & 5399.308 & .000 & 1 & .997 & -10600.147 & 10564.750 \\
\hline & {$[$ DratioClasses $=5]$} & 1.099 & 1.826 & .362 & 1 & .547 & -2.480 & 4.677 \\
\hline \multirow[t]{7}{*}{ Location } & {$[$ DratioClasses $=6]$} & .405 & 1.683 & .058 & 1 & .810 & -2.894 & 3.705 \\
\hline & {$[$ DratioClasses $=8]$} & -17.699 & .000 & . & 1 & . & -17.699 & -17.699 \\
\hline & [DratioClasses $=9]$ & -17.699 & 8537.055 & .000 & 1 & .998 & -16750.019 & 16714.621 \\
\hline & [DratioClasses=11] & -17.699 & 6970.476 & .000 & 1 & .998 & -13679.581 & 13644.183 \\
\hline & [DratioClasses $=13]$ & -17.699 & .000 & . & 1 & . & -17.699 & -17.699 \\
\hline & {$[$ DratioClasses $=14]$} & -17.699 & .000 & . & 1 & . & -17.699 & -17.699 \\
\hline & [DratioClasses=17] & $0^{\mathrm{a}}$ & & . & 0 & . & & \\
\hline
\end{tabular}

Link function: Logit.

a. This parameter is set to zero because it is redundant.

\subsection{Synthesis}

Decision making on capital structure should be a process, in the understanding that it takes place before the actual opportunity financing actions. That being the case, the literature propagated as 'determinants of capital structure' have to operate in two ways: either in advance in a courseeffect relationship, or in-situ. In 'advance' means the determining factors will have to be in place first in order to be factored in the decision making process or financing actions that impact on capital structure. The other way is where the factors operate as control variables in financial transactions of businesses to adjust the proportions of capital and debt in net assets as a long term process. For example where reserves are accumulated in anticipation of economic opportunities, or borrowing restrictions are reinforced for the declining creditworthiness.

The output of this integrated analysis approach does not project any strong evidence on the theoretical determinants of capital structure on corporate finance as prerequisites influencing decisions on it. There is no emergent decisive pattern so far, that could handle the relationship between opportunity financing options and the corporates capital structure. This suggests that for the markets such as DSE there exist other factors such as economic conditions, policy attractions for investments, or attractiveness of the investment opportunities, which might have a bearing on capital structure and not only the theoretical predictions of the tradeoff and pecking order hypotheses. This paper predicts that the capital structure of infant companies is more of a random factor than deliberation of management.

\section{Conclusions}

The discussion in this paper was led by the desire to find out whether the corporate financial managers make decisions on their firms' capital structure driven by certain capital structure level preferences as predicted by the tradeoff theory, and if they factor their desired order of appropriating financing resources in the actual investment opportunity financing processes. An integrated analysis of lagged financial data and managerial subjective data was conducted, revealing no evidence of the managers factoring their preferences in the investment opportunity financing processes they have undertaken. The outcome of the observations suggests that probably capital structure is driven by circumstances such as the suitability and timing of opportunities rather than a planned action.

\subsection{Limitations}

DSE is relatively an emerging market. Majority of the listed companies have high growth potential, yet they do not have enough reserves. They do not have choice except to borrow despite the growing proportion of debt in their net assets. Practically, this could explain the absence of a patterned action for controlling capital structure. Referring to the pecking order theory, there is no enough information provided on which order prevails, except that the DSE companies are financially distressed with low internal capability to exploit their growth opportunities.

To be able to see the existence of a practical pecking order in organizations, there must be observable practices. This is possible if there are actual instances in the corporate world. Quite unfortunately, such instances can prevail with mature entities which are not a norm in many places.

\subsection{Future work}

A similar work is needed for other stock markets in different regions of the world, so as to have a mapping of the finance management community's subjective knowledge on 
the management of capital structure in organizations. It is only then that the finance research community can have a rich understanding of the mechanisms of the 'determinants' of capital structure in organizations.

\section{References}

[1] Al-taani, K. (2013). The relationship between capital structure and firm performance: evidence from Jordan. Journal of Finance, 1 (3), 41-45. doi:10.11648/j.jfa.20130103.11.

[2] Amemiya, T. (1984). Tobit Models: A Survey. Journal of Econometrics, 24, 3-61.

[3] Bekaert, G., Erb, C., Harvey, C., \& Veskanta, T. (1998). Distributional characteristics of Emerging Markets Returns and Asset Allocation. The Journal of International Finance, (Winter), 102-116.

[4] Chang, C., Lee, A. C., \& Lee, C. F. (2009). Determinants of capital structure choice: A structural equation modeling approach. Quarterly Review of Economics and Finance, 49, 197-213. doi:10.1016/j.qref.2008.03.004.

[5] Chen, J. J. (2004). Determinants of capital structure of Chinese-listed companies. Journal of Business Research, 57 (March 2003), 1341-1351. doi: 10.1016/S01482963(03)00070-5.

[6] Chen, L. (2012). How the Pecking-Order Theory Explain Capital Structure. The Journal of International Management, 1-9. Retrieved from www.jimsjournal.org/10 Li-Ju Chenpdf.pdf.

[7] de Jong, A., Kabir, R., \& Nguyen, T. T. (2008). Capital structure around the world: The roles of firm- and countryspecific determinants. Journal of Banking and Finance, 32, 1954-1969. doi:10.1016/j.jbankfin.2007.12.034.

[8] Deesomsak, R., Paudyal, K., \& Pescetto, G. (2004). The determinants of capital structure: Evidence from the Asia Pacific region. Journal of Multinational Financial Management, 14, 387-405. doi:10.1016/j.mulfin.2004.03.001

[9] Fama, E. F., \& French, K. R. (2002). Testing Trade-Off and Pecking Order Predictions about Dividends and Debt.pdf. The Review of Financial Studies, 15 (1), 1-33. doi:10.1093/rfs/15.1.1.

[10] Frank, M., Goyal, V. (2009). Capital Structure Decisions: Which Factors Are Reliably Important ? Journal of Financial Management, 38 (1), 1-37.

[11] Gharaibeh, A. (2015). The Determinants of Capital Structure: Empirical Evidence from Cuwait. European Journal of Business, Economics and Accountancy 3 (6), 1-25.

[12] Hackbarth, D., Hennessy, C. a., \& Leland, H. E. (2007). Can the trade-off theory explain debt structure? Review of Financial Studies, 20, 1389-1428. doi:10.1093/revfin/hhl047.

[13] Huang, G., \& Song, F. M. (2006). The determinants of capital structure: Evidence from China. China Economic Review, 17, 14-36. doi:10.1016/j.chieco.2005.02.007.

[14] Irfan, A. (2011). Determinants of capital structure : Empirical evidence from Pakistan. University of Twente Enschede, Netherlands. Retrieved from http://ssrn.com/abstract=1977024.
[15] Jensen, M. C., \& Meckling, W. H. (1976). Teory of the Firm: Managerial Behaviour, Agency Costs and Ownership Structure. Journal of Financial Economics, 3, 305-360.

[16] Ju, N., Parrino, R., Poteshman, A. M., \& Weisbach, M. S. (2005). Horses and Rabbits? Trade-Off Theory and Optimal Capital Structure. Journal of Financial and Quantitative Analysis, 40 (2), 259. doi:10.1017/S0022109000002301.

[17] Kabir, H. (2010). Positive Accounting Theory and Science. Journal of Centrum Cathedra, 3(2), 136-149. Retrieved from https://scholar-google-co-

za.ezproxy.uct.ac.za/scholar? q=positive + accounting + theory $+\mathrm{a}$ $\mathrm{nd}+$ science\&btnG $=\& \mathrm{hl}=$ en\&as_sdt $=0 \% 2 \mathrm{C} 5$.

[18] Klein, H. H. K., \& Myers, M. D. M. (1999). A set of principles for conducting and evaluating interpretive field studies in information systems. MIS Quarterly, 23 (1), 67-93. doi:10.2307/249410.

[19] Maddala, G. S. (2002). Introduction to Econometrics (3rd ed.). West Sussex, England: John Wiley \& Sons.

[20] Mukras, M. S. (1993). Elementary Econometrics: Theory Application and Policy. Nairobi, Kenya: East African Educational Publishers.

[21] Myers, S. C. (1984). The Capital Structure Puzzle. The Journal of Finance, 39 (3), 575-592.

[22] Myers, S. C. (2001). Capital Structure. The Journal of Economic Perspectives 15 (2), 81-102. doi:10.1257/jep.15.2.81.

[23] Ngonzi, T. (2016). Debating the "Evolution of Accounting Equation": A Cross-Case Analysis Approach. Journal of Finance and Accounting, 4(4,2016), 179-187. doi:10.11648.

[24] Ntui, P. P. (2013). Evolution of Accounting Equation: evidence of companies quoted on Dar es Salaam stock exchange - Tanzania. Journal of Finance and Accounting, 1 (4), 55-63. doi:10.11648/j.jfa.20130104.11.

[25] Qian, Y., Tian, Y., \& Wirjanto, T. S. (2009). Do Chinese publicly listed companies adjust their capital structure toward a target level? China Economic Review, 20 (4), 662-676. doi:10.1016/j.chieco.2009.06.001.

[26] Rajan, R., \& Zingales, L. (1995). What do we know about capital structure? Some evidence from international data. The Journal of Finance, 50 (5), 1421-1460. doi:10.1111/j.15406261.1995.tb05184.x.

[27] Rowlands, B. (2005). Grounded in Practice: Using Interpretive Research to Build Theory. The Electronic Journal of Business Research Methodology, 3 (1), 81-92.

[28] Saudagaran, S. N., \& Diga, J. (1997). Financial Reporting in Emerging Capital Markets. Accounting Horizons, 11 (2), 4164.

[29] Stock, J. H., \& Watson, M. W. (2003). Introduction to Econometrics. Delhi, India: Pearson Education (Singapore) Pte. Ltd.

[30] Tong, G., \& Green, C. J. (2005). Pecking order or trade-off hypothesis? Evidence on the capital structure of Chinese companies. Applied Economics, 37 (July 2014), 2179-2189. doi:10.1080/00036840500319873. 
[31] Watts, R. L., \& Zimmerman, J. L. (1990). Accounting Year Theory: Ten Perspective. Review Literature And Arts Of The Americas, 65 (1), 131-156. Retrieved from http://www.jstor.org/stable/247880.

[32] Welch, I. (2007). Common flaws in empirical capital structure research. AFA 2008 New Orleans Meetings Paper. Retrieved from http://leeds-faculty.colorado.edu/Bhagat/welch-capitalstructure.pdf.
[33] Welch, I. (2011). Two Common Problems in Capital Structure Research: The Financial-Debt-To-Asset Ratio and Issuing Activity Versus Leverage Changes. International Review of Finance, 11(1), 1-17. Retrieved from http://onlinelibrary.wiley.com/doi/10.1111/j.14682443.2010.01125.x/full.

[34] Williams, P. F., \& Francis, J. (1989). The Logic of Positive Accounting Research. Accounting Organizations \& Society 14 (5). 